\title{
Proceeding
}

Supplementary Issue: Autumn Conferences of Sports Science. Costa Blanca Sports Science Events, 18-19 December 2020. Alicante, Spain.

\section{Relationship between performance in youth category and success achievement in senior category in swimming}

\author{
HENRICH KRČ $1 \unlhd$, IVAN ČILLIIK² ${ }^{2}$ PAVOL JELENÁK³ , LUKÁŠ ODRÁŠKA4 \\ ${ }^{1}$ Institute of Physical Education and Sports, Faculty of Medicine, Comenius University in Bratislava, Slovakia \\ ${ }^{2}$ Department of Physical Education and Sports, The Faculty of Arts, Matej Bel University in Banská Bystrica, \\ Slovakia \\ ${ }^{3}$ Department of Outdoor Sports and Swimming, Faculty of Physical Education and Sport, Comenius \\ University in Bratislava, Slovakia \\ ${ }^{4}$ Department of School Education, Faculty of Education, Trnava University in Trnava, Slovakia
}

\begin{abstract}
The aim of this study was to examine the relationship between youth and senior performance in swimming. The sample consisted of 49 men (age $21.24 \pm 3.04$ ) and 35 women (age $19.45 \pm 2.13$ ). The average FINA point score achieved for men was $632.71 \pm 62.86$ points. in women $645.62 \pm 56.71$ points. We included in our comparison performance of seniors achieved in a $25 \mathrm{~m}$ pool in 2019 season and their performance at the age of 12 for men and 11 years for women. The swimmers we monitored were ranked 1 st to $50^{\text {th }}$ in the Slovak Charts in 2019 season. The monitored disciplines were $50 \mathrm{~m}, 100 \mathrm{~m}$, and $200 \mathrm{~m}$ freestyle. To assess the relationship between performance in the youth category and in the senior category we used the mathematical-statistical program IBM SPSS 23 and the nonparametric Spearman correlation coefficient for the ranking data. In the monitored disciplines we did not observe a statistically significant relationship between performance in the youth and senior categories in men or women. In $50 \mathrm{~m}$ freestyle men the values were: $R=0.279, p=.248$. For women: $R=0.114$ and $p=.697$. In 100 m freestyle men the values were: $R=$ $0.218, p=.400$. For women: $R=0.396$ and $p=.203$. In $200 \mathrm{~m}$ freestyle men the values were: $R=0.091, p$ $=.768$. For women: $\mathrm{R}=0.134$ and $p=.730$.
\end{abstract}

Keywords: Swimming; Youth; Senior; Performance.

Cite this article as:

Krč, H., Čillík, I., Jelenák, P., \& Odráška, L. (2021). Relationship between performance in youth category and success achievement in senior category in swimming. Journal of Human Sport and Exercise, 16(2proc), S370-S376. doi:https://doi.org/10.14198/jhse.2021.16.Proc2.21

Corresponding author. Institute of Physical Education and Sports, Faculty of Medicine, Comenius University in Bratislava, Slovakia.

E-mail: henrich.krc@fmed.uniba.sk

Abstract submitted to: Autumn Conferences of Sports Science. Costa Blanca Sports Science Events, 18-19 December 2020. Alicante, Spain.

JOURNAL OF HUMAN SPORT \& EXERCISE ISSN 1988-5202

(c) Faculty of Education. University of Alicante

doi:10.14198/jhse.2021.16.Proc2.21 


\section{INTRODUCTION}

Swimming is one of the most popular sports in Slovakia. After football and hockey, together with athletics, it belongs to the sports with the largest membership base. Nevertheless, our swimmers have not been able to assert themselves internationally for several years. Last time it was in 2016 when Richard Nagy managed to win a medal in a top-ranked swimming event. Before him it was Martina Moravcová in 2006. Currently, advancing to the semi-finals is considered a success at the top even and final participation is above standard. In addition to the number of problems that swimming in Slovakia encounters, the problem of early sports specialization may be common phenomenon that is to blame.

The concept of early sport specialization is not exactly the same for authors, but the essence of the problem is that children who have undergone narrowly specialized training at an early age begin to stagnate in performance and there is little presumption of their success in adulthood. According to Myera et al. (2015) is a concept of early sports specialization related to children, and they define it as an intensive and specific focus on one sport to the exclusion of others.

While the definition of specialization in the early stages of sports training remains unclear, the consensus suggests that intensive and selective participation in a single sport could lead to several problems associated with overload and burnout. (Latorre-Román et al., 2018). According to Moravec et al. (2007) is early sport specialization unilateral burden, which increases the risk of injury under the influence of overloading the points. The most common are premature ossification of bones, diseases of the spine, fatigue fractures. Possible mental disorders from monotonously conducted trainings are also dangerous and the motivation of children to play sports is reduced. According to Kammpmiller (2012) another problem is a large number of anaerobic lactate trainings used at a young age, leading to destabilization, and overtraining, while the young organism does not yet have mature lactate degradation buffer systems.

American Orthopaedic Society for Sports Medicine claims that early sports specialization, or early singlesport specialization, is defined by the following 3 criteria: 1 . Participation in intensive training and/or competition in organized sports greater than 8 months per year (essentially year-round) (Jayanthi et al., 2015); 2. Participation in one sport to the exclusion of participation in other sports (limited free play overall) (Jayanthi et al., 2012); 3. Involving prepubertal (seventh grade or roughly age 12 years) children (LaPrade et al., 2016).

Kučera et al. (2011) consider swimming to be a suitable physical activity for children for the possibility of targeted and adequate strengthening of the whole organism as well as its parts, especially muscles. It has a direct effect on posture, respiration, and blood circulation. However, this does not mean that during swimming training the individual will only spend time in the aquatic environment. They emphasize that children's training should be a combination of specific, general, and compensatory exercises.

When it comes to swimming in Slovakia, there are many unconfirmed examples that coaches who do not follow scientific and methodological recommendations and train more with children, achieve high performance in pupil and youth categories, but their success in senior categories is lower. There are no scientific papers in Slovakia dealing with specific data that would refute or confirm these views.

The aim of this study is to point out the relationship between special performance in the category of younger pupils aged 11-12 years and performance in the category of seniors, based on a comparison of tabular performance from 7-8 years ago. 


\section{METHODS}

The sample consisted of 49 men (age $21.24 \pm 3.04$ ) and 35 women (age $19.45 \pm 2.13$ ). The average FINA point score achieved in men was $632.71 \pm 62.86$ points, in women $645.62 \pm 56.71$ points.

\section{Measures}

In the comparison we included the performance of seniors achieved in the $25 \mathrm{~m}$ pool in 2019 season. We compared their performance with the performance at the age of 12 for men and 11 for women. The swimmers we monitored were ranked 1st to 50th in the Slovak charts in 2019 season. The monitored disciplines were $50 \mathrm{~m}, 100 \mathrm{~m}$, and $200 \mathrm{~m}$ freestyle. As a criterion variable we chose the best achieved point performance in the monitored period. We obtained the monitored performance indicators from the website of the Slovak Swimming Federation using software swimrankings.net (www.swimmsvk.sk).

\section{Analysis}

We used the mathematical-statistical program IBM SPSS 23 and the nonparametric Spearman correlation coefficient for the ranking data to assess the relationship between performance in the youth category and in the senior category.

\section{RESULTS}

In the present work, we tried to reveal the relationship between youth and senior performance in swimming. In total, we watched three swimming disciplines $50 \mathrm{~m}, 100 \mathrm{~m}$, and $200 \mathrm{~m}$ freestyle men and women.

Table 1. Performance in the senior and youth category in the $50 \mathrm{~m}$ freestyle men.

\begin{tabular}{lccccc}
\hline & \multicolumn{2}{c}{ Senior } & \multicolumn{3}{c}{ Youth } \\
\cline { 2 - 6 } & Time [s] & Points [n] & Time [s] & Points [n] & Difference [s] \\
\hline AVG & 23.89 & 613.4 & 30.88 & 298 & 6.99 \\
SD & 0.779 & 63 & 3.26 & 76 & 2.481 \\
Max & 24.88 & 761 & 41.5 & 475 & 16.62 \\
Min & 22.19 & 539 & 25.96 & 116 & 3.77 \\
\hline
\end{tabular}

Table 2. Performance in the senior and youth category in the $50 \mathrm{~m}$ freestyle women.

\begin{tabular}{lccccc}
\hline & \multicolumn{2}{c}{ Senior } & \multicolumn{3}{c}{ Youth } \\
\cline { 2 - 6 } & Time [s] & Points [n] & Time [s] & Points [n] & Difference [s] \\
\hline AVG & 26.84 & 625.5 & 32.84 & 348 & 6.00 \\
SD & 0.72 & 48.75 & 2.14 & 63 & 1.42 \\
Max & 28.05 & 697 & 37.7 & 453 & 9.65 \\
Min & 25.85 & 546 & 29.84 & 225 & 3.99 \\
\hline
\end{tabular}

Table 3. Performance in the senior and youth category in the $100 \mathrm{~m}$ freestyle men.

\begin{tabular}{lccccc}
\hline & \multicolumn{2}{c}{ Senior } & \multicolumn{2}{c}{ Youth } & \\
\cline { 2 - 6 } & Time [s] & Points [n] & Time [s] & Points [n] & Difference [s] \\
\hline AVG & 52.28 & 637.1 & 70.31 & 302 & 18.03 \\
SD & 1.323 & 48.54 & 9.26 & 124 & 7.93 \\
Max & 54.15 & 734 & 91.0 & 613 & 36.85 \\
Min & 49.8 & 571 & 59.25 & 120 & 9.45 \\
\hline
\end{tabular}


Table 4. Performance in the senior and youth category in the $100 \mathrm{~m}$ freestyle women.

\begin{tabular}{lccccc}
\hline & \multicolumn{2}{c}{ Senior } & \multicolumn{3}{c}{ Youth } \\
\cline { 2 - 6 } & Time [s] & Points [n] & Time [s] & Points [n] & Difference [s] \\
\hline AVG & 58.48 & 635.6 & 71.81 & 351 & 13.33 \\
SD & 1.291 & 41.09 & 5.60 & 66 & 4.3 \\
Max & 60.62 & 681 & 86.5 & 433 & 25.8 \\
Min & 57.1 & 569 & 66.39 & 196 & 9.29 \\
\hline
\end{tabular}

Table 5. Performance in the senior and youth category in the $200 \mathrm{~m}$ freestyle men.

\begin{tabular}{lccccc}
\hline & \multicolumn{2}{c}{ Senior } & \multicolumn{2}{c}{ Youth } & \\
\cline { 2 - 6 } & Time [s] & Points [n] & Time [s] & Points [n] & Difference [s] \\
\hline AVG & 115.6 & 637.8 & 160.22 & 286 & 44.62 \\
SD & 3.658 & 61.7 & 21.12 & 84 & 17.46 \\
Max & 122.1 & 758 & 203.0 & 455 & 80.9 \\
Min & 109 & 538 & 129.1 & 117 & 20.1 \\
\hline
\end{tabular}

Table 6. Performance in the senior and youth category in the $200 \mathrm{~m}$ freestyle women.

\begin{tabular}{lccccc}
\hline & \multicolumn{2}{c}{ Senior } & \multicolumn{2}{c}{ Youth } & \\
\cline { 2 - 6 } & Time [s] & Points [n] & Time [s] & Points [n] & Difference [s] \\
\hline AVG & 127.2 & 658.7 & 154.41 & 371 & 27.21 \\
SD & 4.295 & 68.57 & 8.17 & 55 & 3.87 \\
Max & 131.6 & 774 & 171.9 & 442 & 40.3 \\
Min & 120.2 & 591 & 145 & 265 & 24.8 \\
\hline
\end{tabular}

The following findings can be read from Tables 1-6:

The variance in the performance of the monitored groups is significantly lower in the category of seniors (9.16 $\%)$ compared to the youth category $(40.5 \%)$.

Female pupils in the monitored disciplines achieved on average $16.69 \%$ higher points than males.

In the senior category, the difference in point performance between the sexes was negligible (1.6\%).

The percentage increase in performance between the youth and senior categories was higher in men $113 \%$ compared to women $79 \%$.

From the whole monitored group for all disciplines and genders. $70 \%$ of swimmers achieved a better table placement in the youth category compared to the senior category. Ratio of senior swimmers placed in top 5 achieving better ranking in the youth tables was only $50 \%$. Among the top three seniors, $44 \%$ achieved a better charts position in the youth category.

Of the best pupils in our group (placed in the top 3 in the student charts), better placement in the senior charts was achieved by only $10 \%$.

We did not record a statistically significant relationship in the monitored disciplines in either men or women (Table 7). 
Table 7. R-Spearman correlation coefficient; $p$-statistical significance.

\begin{tabular}{lll}
\hline 50 Freestyle & Men $[n=19]$ & Women $[n=14]$ \\
& $R=0.279$ & $R=0.114$ \\
& $p=.248$ & $p=.697$ \\
\hline \multirow{3}{*}{ 100 Freestyle } & Men $[n=17]$ & Women $[n=12]$ \\
& $R=0.218$ & $R=0.396$ \\
& $p=.400$ & $p=.203$ \\
\hline & Men $[n=13]$ & Women $[n=9]$ \\
& $R=0.091$ & $R=0.134$ \\
& $p=.768$ & $p=.730$ \\
\hline
\end{tabular}

\section{DISCUSSION}

The results showed that we did not confirm a statistically significant relationship in any of the monitored disciplines, we did not find a relationship between performance in the student and senior categories in either the men's or women's disciplines. Gulbin et al. (2013) in 256 elite sportsmen in 27 different sports finds that substantial variability regarding starting age, pattern of ascent and magnitude of transition was apparent. Non-linear trajectories were experienced by the majority of athletes $(83.6 \%)$. with pure junior to senior developmental linearity evident in less than $7 \%$ of cases. Athletes in cgs sports (those measured in centimetres. grams or seconds) were less likely (43\%) to experience a descending trajectory in comparison with non-cgs athletes (70\%; $p<.001)$. The collective findings of this investigation demonstrate the opposite of the popular to the popular pyramidal concept of athlete development. A single linear assault on expertise is rare and the common normative junior to senior competition transition is mostly characterised by complex oscillations featuring highly varied transitions. Yustres et al. (2017) in their study point out that there is no evidence to conclude that a finalist position in Swimming Junior WC have influence in achieving success in FINA WC. Larson et al. (2019) revealed in their work that high training volume in youth swimming led to negative physical and emotional consequences and scheduling conflicts between swimming and other activities. Stagnation in performance led to a dropout in youth swimming. In contrast, the continuers' focus on enjoyment, social aspects, and other non-performance-related reasons for swimming led to a smooth transition from youth swimming into masters swimming.

An interesting phenomenon was discovered by the authors Latorre-Román et al. (2018). There were 1.144 participants, 594 males and 550 females. All the athletes who ranked at that time (2004) in top 10 were between 14-19 years belonging to the following categories: cadet (14-15 years), youth (16-17 years) and juniors (19-19 years) in both sexes. There was a significant reduction of athletes in top 10 from 2004 to 2014. Of the 1.144 athletes taken into consideration in 2004, $1.104(96.50 \%)$ were considered as dropouts from high performance in 2014. Whereof 543 (98.72\%) were women and 561 (94.45\%) were men. Considering the athletic disciplines and the overall analysis, sprint, and hurdles in males (99.4\%) and middle/long running and walks in females $(100 \%)$ showed the highest percentage of dropouts. These results oppose the idea that success at a young age (i.e., top 10 ranking) ensures later success. Here we can see a certain parallel with our research, when in the charts for 2019 among our senior swimmers, who are in the first place; there is no-one who was first place in the charts of the youth age.

In the world of sports training, it has not been valid for a long time that the more I train, the better. Such an approach brings results and significant improvement in the categories of pupils and juniors. Therefore, there is a negative effect of early sports specialization when young swimmers end for various reasons. An example is long-term mental or physical exhaustion. Further explanation can be found in different biological 
development during the category of pupils. The difference between two individuals of the same calendar age can be up to 4 biological years. If we have a biologically accelerated individual in the youth category and a biologically retarded individual, it is clear that in the mutual comparison the accelerated individual will dominate. The level of talent in this case will play no role. During ontogenesis, the differences between two individuals aligned and if one of them is better placed to achieve top athletic performance sooner or later this will be reflected. In this case, similarly to the early sports specialization, the individual who dominated in the youth categories does not have to assert himself in the senior category at all. Looking at the above-mentioned facts, it is evident that in order for a young athlete to assert himself in the senior categories. he does not have to excel among the pupils. Our view of the issue is not sufficient to formulate general conclusions, but it indicates a certain risk of early sports specialization and a need for all-round development of a young organism in the pursuit of future sports championships. However, each organism is different and what applies to one may not apply to the other. It remains the task of coaches and parents to monitor their children and trustees and look for the most optimal way to develop sports performance. Another aspect to consider is the health risks resulting from long-term overload of the young organism. as pointed out by several authors, e.g., Kučera et al. (2011); Kreher \& Schwartz (2012); Booth, Roberts \& Laye (2012).

\section{CONCLUSIONS}

Relationship between performance in youth category and achievement of success in senior category in swimming was assessed using the Spearmen correlation coefficient. We assessed the observed relationship for the disciplines $50 \mathrm{~m}, 100 \mathrm{~m}$, and $200 \mathrm{~m}$ freestyle. The monitored group consisted of currently the best senior swimmers in Slovakia, whose performance data we obtained from the swimmrankings.net portal. Subsequently, we correlated their performance with their performance in the age of pupils.

We did not observe a statistically significant relationship between performance in the youth and senior monitored categories in either men or women. In 50 m freestyle men the values were: $R=0.279, p=.248$. For women: $R=0.114$ and $p=.697$. In $100 \mathrm{~m}$ freestyle men the values were: $R=0.218, p=.400$. For women: $R=0.396$ and $p=.203$. In $200 \mathrm{~m}$ freestyle men the values were: $R=0.091, p=.768$. For women: $R=0.134$ and $p=.730$.

No-one of the pupil categories who was in the first place reached the first place in the senior category Only $10 \%$ of the pupils reached better ranking in senior charts compared to their earlier performance. The results of our research suggest that Slovak coaches train in swimming mostly in a way that the training brings results and significant improvement in the categories of pupils and juniors. In such a case, the prospects of their trustees are very uncertain and confirm their views on early sport specialization in swimming, which brings health, psychological and didactic risks.

\section{REFERENCES}

Booth F. W., Roberts C. K., Laye M. J. (2012, April). Lack of exercise is a major cause of chronic diseases. Comprehensive Physiology, 2(2), 1143-1211. https://doi.org/10.1002/cphy.c110025

Gulbin J., Weissensteiner J., Oldenziel K., Francoys. G. (2013, January). Patterns of performance development in elite athletes. European Journal of Sport Science, 13(6), 605-14. https://doi.org/10.1080/17461391.2012.756542

Jayanthi N., Pinkham C., Dugas. L., Patrick B., Labella. C. (2013, May). Sports specialization in young athletes: evidence-based recommendations. Sports Health, 5(3), 251-257. https://doi.org/10.1177/1941738112464626 
Jayanthi N.A., LaBella C.R., Fischer D., Pasulka J., Dugas L.R. (2015, February). Sports-Specialized Intensive Training and the Risk of Injury in Young Athletes: A Clinical Case-Control Study. The American Journal of Sports Medicine, 794-801. https://doi.org/10.1177/0363546514567298

Kampmiller T., Vanderka M., Laczo E., Peráček P. (2012). Teória športu a didaktika športového tréningu. ICM Agency: Bratislava.

Kreher J. B., Schwartz J. B. (2012, January). Overtraining Syndrome: A Practical Guide. Sports Health, 4(2), 128-138. https://doi.org/10.1177/1941738111434406

Kučera M., Kolář P., Dylefreestyleký I. (2011). Dítě, sport a zdraví. Praha: Galén.

Laprade R. F., Agel J., Baker J., Brenner J. S., Cordasco F. A., Côté J., Hewett T. E. (2016, April). AOSSM early sport specialization consensus statement. Orthopaedic Journal of Sports Medicine, 4(4), 1-6. https://doi.org/10.1177/2325967116644241

Larson H.K., Mchugh F.L., Young. W.B., Rodgers. W.M. (2019, March). Pathways from youth to masters swimming: Exploring long-term influences of youth swimming experiences. Psychology of Sport and Exercise, 41, 12-20. https://doi.org/10.1016/j.psychsport.2018.11.007

Latorre-Román P.Á., Pinillos F.G., Robles J.L. (2018, September). Early sport dropout: High performance in early years in young athletes is not related with later success. Retos: Nuevas tendencias en Educación Física. Deporte y Recreación, 33, 210-212. https://doi.org/10.47197/retos.v0i33.58225

Moravec R., Kampmiller T., Vanderka M., Laczo E. (2007). Teória a didaktika výkonnostného a vrcholového športu. Bratislava: Fakulta telesnej výchovy a športu Univerzita Komenského.

Myer G.D., Jayanthi N., Difiori J.P., Fagenbaum A.D., Kiefer A.W., Logerstedt D., Micheli L.J. (2015, August). Sport Specialization, Part I: Does Early Sports Specialization Increase Negative Outcomes and Reduce the Opportunity for Success in Young Athletes?. Sports Health,.7(5), 437-442. https://doi.org/10.1177/1941738115598747

Slovenská plavecká federácia. (2019). Výsledky plávania. Retrieved December 12, 2020, from: https://swimmsvk.sk/vysledky/plavanie?page=rankingDetail\&clubld=353\&gender=1\&season=2019 \&course=SCM\&agegroup $=19000$ \&stroke $=1$

Yustres I., Martín R., Fernández L., González-Ravé J.M. (2017, November). Swimming championship finalist positions on success in international swimming competitions. PLoS One, 12(11). https://doi.org/10.1371/journal.pone.0187462

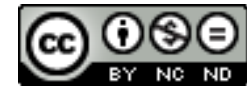

This work is licensed under a Attribution-NonCommercial-NoDerivatives 4.0 International (CC BY-NC-ND 4.0). 